\title{
Process standardization for enhancing biofunctionality of dahi
}

\begin{abstract}
Global inclination of consumers towards healthful foods has resulted in a renewed interest in dahi consumption owing to its functional properties. Diversity in chemical and microbiological attributes of $d a h i$ has been noted due to adoption of different manufacturing technology. Process standardization for its production is emerging to obtain a consistent product with enhanced functional properties to project it in the world of functional food market. Based upon post-acidification, volatile acidity and syneresis conjugate application of eXact Dahi 2+YoFlex Express 1.0 (Half Concentration)+STI-13 in milk (15.30\% TS) and an incubation temperature of $47 \pm 1^{\circ} \mathrm{C} / 5 \mathrm{~h}$ was found optimum to obtain dahi with enhanced biofunctionality and was microbiologically safe, which retained all desirable properties upto 7 days of storage at $8 \pm 1^{\circ} \mathrm{C}$. Biofunctionality of dahi may be attributed to higher proteolytic activity of starter cultures, higher ash content and retention of viability of starter cultures $\left(10^{7} \mathrm{cfu} / \mathrm{g}\right)$ required for exhibiting health benefits. Ingestion of dahi obtained by method employed in the present investigation as functional food is suggested.
\end{abstract}

Volume 9 Issue I - 2019

\author{
Sarkar S, Sarkar K, Majhi R, Chatterjee K, \\ Sikder B, Sur A \\ Metro Dairy Limited, India
}

Correspondence: Sarkar S, Metro Dairy Limited, BarrackporeBarasat Link Road, Subhasnagar, P.O. Neelgunj Bazar, Kolkata-700 I2I,West Bengal, India, Email

drsurajitsarkar@yahoo.co.in

Received: November 30, 2018 | Published: January 15, 2019

Keywords: dahi, biofunctionality, health effects, functional food

\section{Introduction}

Recent trend of consumers towards healthful foods due to increased awareness and knowledge ${ }^{1}$ has led to the development of functional dairy products that basically provide health benefits in addition to their fundamental nutrients. ${ }^{2}$ Dahi is considered the oldest Indian fermented milk product and may be considered the western equivalent to yoghurt. Dietetic significance of dahi is well documented. $^{3-5}$ and consumer's inclination towards healthful foods has resulted in renewed interest in dahi. Functional properties of $d a h i^{6}$ and probiotic supplemented food have projected them as a functional food in the current era of self-care and complementary medicine. ${ }^{7}$ Reviewed literature indicated that functional properties of traditional dahi could be enhanced either by manipulation of fortifying ingredients of basic mix, starter combinations, incubation temperature and time, ${ }^{6}$ introduction of probiotic cultures and inclusion of diverse food additives such as fruit juices, herbs and spices, ${ }^{8,9}$ which would help towards process standardization and project them into the global market as a functional food. ${ }^{6}$

In an earlier investigation, ${ }^{10}$ recommended conjugated application of eXact Dahi 2+YoFlex Express 1.0 and an incubation temperaturetime combination of $45 \pm 1^{\circ} \mathrm{C} / 5 \mathrm{~h}$ to obtain dahi with hard smooth body, titratable acidity $(0.88 \%$ lactic acid $)$, volatile acidity $(1.40 \mathrm{ml}$ of $0.1 \mathrm{~N}$ $\mathrm{NaOH} / 50 \mathrm{~g}$ curd) and syneresis $(2.23 \%)$ but it did not evaluated the impact of composition of basic mix, incubation conditions and starter combinations on biofunctionality of dahi. In the present research an attempt has been taken towards process standardization for the manufacture of dahi with enhanced bio-functionality.

\section{Materials and methods}

\section{Type of milk}

Milk intended for dahi manufacture was standardized to 3.30 $3.40 \%$ fat and $11.00-12.00 \% \mathrm{snf}$ by blending raw mixed milk received from Nadia and Murshidabad districts of West Bengal, India with BIS standard skim milk powder and white butter. Milk was homogenized (Stage I - 2500 psi, Stage II - $500 \mathrm{psi})$ and pasteurized $\left(74-78^{\circ} \mathrm{C} / 16\right.$ $19 \mathrm{sec}$ ) prior to seeding with diverse starter cultures to obtain dahi (Figure 1).
STANDARDIZED MILK

$(3.40-3.50 \%$ Fat, $11.00-12.00 \%$ Snf)

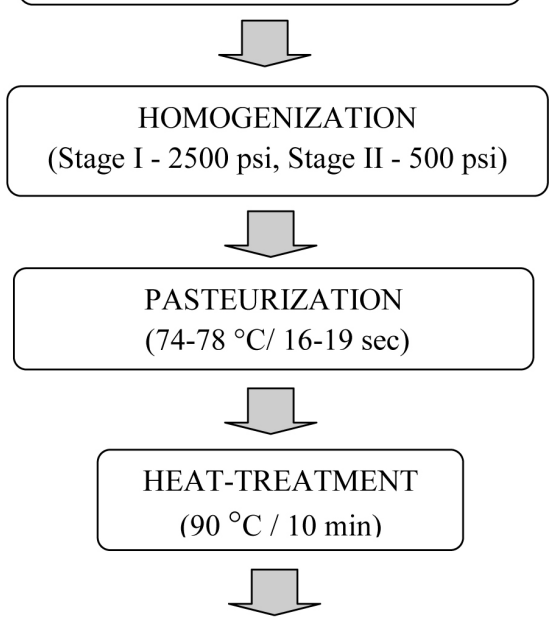

COOLING \& INOCULATION $\left(47 \pm 1^{\circ} \mathrm{C}\right)$

(eXactDahi $2+$ Yo Flex Express $1.0(\mathrm{H})+$ STI-13)

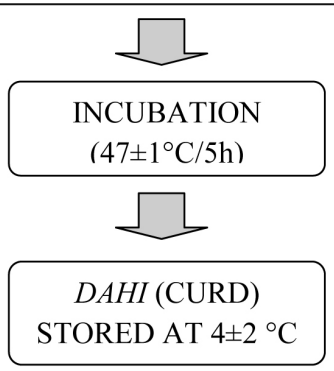

Figure I Method of production of biofunctional dahi.

\section{Starter cultures}

Direct to-vat inoculation cultures of Yo Flex Express 1.0, eXact Dahi 2, STI-13 and RST - 743 obtained from Chr Hansen, USA were applied in diverse combinations to obtain dahi. 


\section{Process standardization for dahi manufacture with enhanced bio-functionality}

Raw milk free from different preservative and adulteration was standardized for dahi manufacture. Homogenized and pasteurized standardized milk was subjected to the suggested heat-treatment of $90^{\circ} \mathrm{C} / 10 \mathrm{~min},{ }^{11}$ followed by cooling to 30 to $45^{\circ} \mathrm{C}$ for inoculation with selected starter combinations. Inoculated milk was then incubated for $5 \mathrm{~h}$ to obtain firm curd. Based upon biochemical (acidification, post acidification, volatile acid production), chemical (total solids, fat, protein and ash) and rheological characteristics during 7days of storage at $8 \pm 1{ }^{\circ} \mathrm{C}$, dahi with enhanced biofunctionality was selected.

\section{Chemical attributes}

Samples of raw milk were tested for the presence of different preservative and adulteration by the methods suggested by FSSAI (2015). Titratable acidity, \% Fat and \% snf of standardized milk was determined by the methods of BIS. ${ }^{13}$ Dahi was analysed for fat, ash content, titratable acidity ${ }_{1}^{14}$ volatile acidity, ${ }^{15}$ total solids using Moisture Analyzer-HB43-S (Mettler Toledo, Switzerland) and protein using 2006 Digestor and Kjeltec System 1002 Distilling Unit (Foss, Denmark).

\section{Rheological attributes}

Syneresis of dahi was determined by centrifuging $50 \mathrm{ml}$ of $d a h i$ at $2600 \mathrm{rpm}$ at $8^{\circ} \mathrm{C}$ for $10 \mathrm{~min}$ and expressed as a weight percentage of the whey separated from the gel over the initial weight of the gel. ${ }^{16}$

\section{Microbiological attributes}

Microbiological attributes of dahi obtained employing selected starter combination was evaluated on the basis of total viable microbial contents using nutrient agar (Hi-Media, Bombay, India), coliform count, Escherichia coli, Salmonella count using MacConkey agar (Merck, Germany), Listeria monocytogens using autoclaved Polymixin Acriflavine Lithium Chloride Ceftazidime Esculin Mannitol (PALCAM) broth and agar (Merck, Germany), yeast and mould using potato dextrose agar (Hi-Media, Bombay, India) adopting the methods of Bureau of Indian standards..$^{13}$

\section{Results and discussion}

\section{Effect of incubation condition and milk composition on starter activity}

\section{Post-acidification}

Development of lactic acid under controlled conditions during fermentation is essential for the formation of yoghurt gel network. The acidification process results in the formation of three-dimensional network consisting of cluster and casein chains. ${ }^{17}$ On the contrary, development of acidity after the fermentation is not desired as it leads to wheying-off, textural defects and excess sourness, which suppresses the perception of aroma compounds. ${ }^{18}$ An elevation in incubation temperature from $45 \pm 1$ to $47 \pm 1^{\circ} \mathrm{C}$ induced no change in extent of post-acidification (1.00 vs. $1.01 \%$ titratable acidity). However, Walstra et al. ${ }^{19}$ reported predominance of Lactobacillus spp. with a slight increase in incubation temperature above $45^{\circ} \mathrm{C}$. Discrepancies in research finding could be attributed to type of milk or strains of cultures employed.

Further, attempt was taken to investigate effect of two-stage fermentation on the growth characteristics of starter cultures (Table 1) as the optimum growth temperature of eXact Dahi 2 and YoFlex Express 1.0 are $30^{\circ} \mathrm{C}$ and $42^{\circ} \mathrm{C}$, respectively. Two-stage fermentation (initial incubation at $37^{\circ} \mathrm{C} / 2 \mathrm{~h}$ followed by incubation at $47 \pm 1^{\circ} \mathrm{C} / 3 \mathrm{~h}$ ) resulted in higher rate of acid production ( 1.13 vs. $1.01 \%$ titratable acidity). Higher post-acidification due to two stage fermentation in contrast to single stage incubation indicated inhibition or retarded culture growth at elevated incubation temperature. Extent of acidification encountered either due to elevation of incubation temperature or twostage fermentation was beyond the FSSAI specification $(0.70-0.90 \%)$ for $d a h i^{14}$ and is not recommended as it leads to wheying-off, textural defects and excess sourness.

Table I Effect of incubation condition and milk composition on starter activity

\begin{tabular}{|c|c|c|c|c|c|c|c|c|c|c|c|}
\hline \multirow{3}{*}{ Starter Cultures } & \multirow{3}{*}{$\begin{array}{l}\text { Incubation } \\
\text { Conditions }\end{array}$} & \multirow{3}{*}{$\begin{array}{c}\text { Total } \\
\text { Solids } \\
(\%)\end{array}$} & \multicolumn{3}{|c|}{$\begin{array}{l}\text { Post-Acidification } \\
\text { (\% Lactic acid) }\end{array}$} & \multicolumn{3}{|c|}{$\begin{array}{c}\text { Volatile Acidity } \\
\text { (ml 0.IN NaOH/50g curd) }\end{array}$} & \multicolumn{3}{|c|}{ Syneresis (\%) } \\
\hline & & & \multicolumn{9}{|c|}{ After storage at $8 \pm 1^{\circ} \mathrm{C}$ (days) } \\
\hline & & & 0 & 3 & 7 & 0 & 3 & 7 & 0 & 3 & 7 \\
\hline Dahi + Yoghurt & $47 \pm 1^{\circ} \mathrm{C} / 5 \mathrm{~h}$ & 15.30 & 0.75 & 0.93 & I.0I & 2.20 & 2.40 & 2.00 & II.27 & 9.50 & 13.11 \\
\hline Dahi + Yoghurt & $\begin{array}{l}1-37^{\circ} \mathrm{C} / 2 \mathrm{~h} \\
11-47 \pm 1^{\circ} \mathrm{C} / 3 \mathrm{~h}\end{array}$ & 15.30 & 0.79 & 0.95 & 1.13 & 1.90 & 2.00 & 2.89 & 10.28 & 9.37 & 8.83 \\
\hline Dahi + Yoghurt + STI-I3 & $47 \pm 1^{\circ} \mathrm{C} / 5 \mathrm{~h}$ & 15.30 & 0.96 & 0.98 & 1.05 & 2.11 & 2.90 & 1.67 & 4.09 & 3.65 & 6.54 \\
\hline Dahi + Yoghurt + RST-743 & $47 \pm 1^{\circ} \mathrm{C} / 5 \mathrm{~h}$ & 15.30 & 0.97 & 0.97 & 1.00 & 0.78 & $\mathrm{I} .44$ & 1.55 & 4.82 & 5.30 & 12.62 \\
\hline Dahi (D) + STI-I3 & $47 \pm 1^{\circ} \mathrm{C} / 5 \mathrm{~h}$ & 15.29 & 0.89 & 0.95 & 0.99 & 1.33 & 0.89 & 1.33 & 15.75 & 16.02 & 16.93 \\
\hline Dahi (D) + RST-743 & $47 \pm 1^{\circ} \mathrm{C} / 5 \mathrm{~h}$ & 15.29 & 0.87 & 0.92 & 0.96 & 1.33 & 1.67 & I.II & 20.15 & 19.27 & 11.02 \\
\hline Dahi + Yoghurt + STI-I3 & $47 \pm 1^{\circ} \mathrm{C} / 5 \mathrm{~h}$ & 14.40 & 0.98 & 1.00 & 0.94 & 1.80 & 1.10 & 1.06 & 13.68 & 13.60 & 13.62 \\
\hline Dahi + Yoghurt $(\mathrm{H})+\mathrm{STI}-\mathrm{I} 3$ & $47 \pm 1^{\circ} \mathrm{C} / 5 \mathrm{~h}$ & 14.40 & 0.94 & 0.95 & 0.92 & 2.46 & 1.65 & 0.89 & 12.37 & || $.2 \mid$ & 9.03 \\
\hline
\end{tabular}

Dahi, eXact Dahi 2; Yoghurt, YoFlex Express I.0;Yoghurt (H), Half inoculum of Yoghurt 
Associative growth of STI-13 and RST-743 with eXact Dahi 2 and YoFlex Express 1.0 induced higher rate of acidification ( 0.96 to 0.97 vs. $0.75 \%$ lactic acid) at 0 day of storage. However, eXact Dahi 2 and YoFlex Express 1.0 showed lower acidification (1.00\% lactic acid), when used in conjunction with RST-743 after 7days of storage at $8 \pm 1{ }^{\circ} \mathrm{C}$ (Table 1), indicating antagonistic growth behavior amongst cultures. Associative growth of eXact Dahi 2 (Double inoculum) with STI -13 and RST - 743 were also evaluated. No difference in the extent of acid production by eXact Dahi 2 could be registered when grown in association with either STI - 13 (0.99\% lactic acid) or RST - 743 $\left(0.96 \%\right.$ lactic acid) after 7 days of storage at $8 \pm 1^{\circ} \mathrm{C}$ (Table 1). Extent of acidification by starter cultures is influenced by its concentration of inoculum ${ }^{20}$ and lactose utilization and acid production increased with the increase in inoculum size up to $2 \%(\mathrm{v} / \mathrm{v})$ but no improvement noted at higher inoculum size. ${ }^{21}$ Effect of total solid (TS) content of milk on starter activity was also investigated. Lowering of TS from 15.30 to $14.40 \%$ induced no change in extent of acidification, irrespective of inoculum size of YoFlex Express 1.0. Extent of acidification by starter cultures differs with the type of milk ${ }^{22}$ due to difference in buffering capacity, which is proportional to the total solids content of milk. ${ }^{23}$ Research revealed that inoculation of milk $(15.30 \%$ TS) with a starter combination comprising of eXact Dahi $2+$ YoFlex Express 1.0 + STI - 13 and an incubation temperature of $47 \pm 1^{\circ} \mathrm{C} / 5 \mathrm{~h}$ is suggested to obtain dahi with hard body.

\section{Volatile acidity}

Metabolic activities of starter cultures differ with the type of milk resulting in diverse fermented products with distinct chemical composition and different volatile compounds. ${ }^{24,25}$ reported that flavour profile of fermented milk is associated with the non-volatile acids (lactic or pyruvic), volatile acids (butyric to acetic), carbonyl compounds (acetaldehyde to diacetyl) and miscellaneous compounds (amino acids or products formed due to thermal degradation). An elevation in incubation temperature from $45 \pm 1$ to $47 \pm 1^{\circ} \mathrm{C}$ induced a significant increase in volatile acidity $(1.40$ vs. $2.40 \mathrm{ml}$ of $0.1 \mathrm{~N}$ $\mathrm{NaOH} / 50 \mathrm{~g}$ curd). Similarly, Two-stage fermentation (initial incubation at $37^{\circ} \mathrm{C} / 2 \mathrm{~h}$ followed by incubation at $47 \pm 1^{\circ} \mathrm{C} / 3 \mathrm{~h}$ ) resulted in higher rate of volatile acidity production $(2.89 \mathrm{vs} .2 .00 \mathrm{ml}$ of $0.1 \mathrm{~N} \mathrm{NaOH} / 50 \mathrm{~g}$ curd) after 7 days of storage at $8 \pm 1^{\circ} \mathrm{C}$ (Table 1). Incubation at $>45^{\circ} \mathrm{C}$ induced predominance of acetaldehyde producing $L$. delbrueckii ssp. bulgaricus in contrast to diacetyl producing $S$. thermophilus. Higher levels of volatile acid production by eXact Dahi $2+$ YoFlex Express 1.0 were noted when used in association with STI - 13 in contrast to RST - 743. In the present investigation volatile acid produced by eXact Dahi $2+$ YoFlex Express 1.0 in association with STI - 13 was higher $(2.11 \mathrm{ml}$ of $0.1 \mathrm{~N} \mathrm{NaOH} / 50 \mathrm{~g}$ curd) than those noted in combination with RST-743 $(1.55 \mathrm{ml}$ of $0.1 \mathrm{~N} \mathrm{NaOH} / 50 \mathrm{~g}$ curd) or in earlier report (1.40ml of $0.1 \mathrm{~N} \mathrm{NaOH} / 50 \mathrm{~g}$ curd) by Sarkar et al. ${ }^{26}$

Discrepancies in results may be attributed to different composition of milk or incubation conditions or antagonism amongst starter cultures resulting in shift in proportions of starter combinations. Guler and Gursoy-Balci ${ }^{24}$ mentioned diversity in metabolic activities of starter cultures due to the type of milk resulting in products with distinct chemical composition and different volatile compounds. Dan et al. ${ }^{27}$ reported diversity in production of volatile flavouring compounds with different proportion of yoghurt cultures. Dahi culture produced higher ( $32.5 \mathrm{vs.} 29.2 \mathrm{ml}$ of $0.1 \mathrm{~N} \mathrm{NaOH} / 50 \mathrm{~g}$ curd) volatile acid in buffalo milk than in cow milk ${ }^{28}$ and inclusion of probiotic cultures induced lowering ( 36.0 to $15.8 \mathrm{ml}$ of $0.1 \mathrm{~N} \mathrm{NaOH} / 50 \mathrm{~g}$ curd) of volatile acidity. ${ }^{29}$ Effect of total solid (TS) content of milk on starter activity was also investigated. Lowering of TS from 15.52-15.73 to $14.64 \%$ induced significant decline in extent of volatile acid $(\mathrm{ml}$ of 0.1 $\mathrm{N} \mathrm{NaOH} / 50 \mathrm{~g}$ curd) production (2.11 to 1.67 vs. 1.80 to 1.06 ), during 7 days of storage at $8 \pm 1^{\circ} \mathrm{C}$ (Table 1), which was in accordance with the previous findings. Amongst L. bulgaricus and S. thermophilus, the former organism produces more aroma compounds than the latter ${ }^{30}$ and increasing of milk total solids from 16 to $23 \mathrm{~g} / 100 \mathrm{~g}$ improved the growth of L. bulgaricus ${ }^{31}$ However, lowering of inoculum size of YoFlex Express 1.0 induced the highest volatile acid $(\mathrm{ml}$ of $0.1 \mathrm{~N}$ $\mathrm{NaOH} / 50 \mathrm{~g}$ curd) production at 0 day (2.46), which declined to the lowest value after 7 days (8.89) of storage. Guler and Gursoy-Balci ${ }^{24}$ recorded variation in diacetyl content of yoghurt with the type of milk, culture used and the interaction between storage time and culture used. Based upon flavour profile a starter combination consisting of Dahi + Yoghurt + STI-13 in milk (15.30\% TS) and an incubation temperature of $47 \pm 1^{\circ} \mathrm{C} / 5 \mathrm{~h}$ is suggested to obtain dahi.

\section{Syneresis}

A portion of lactic acid produced by starter cultures combines with calcium to form calcium lactate. The casein devoid of calcium is coagulated at isoelectric point and the fermentation is accompanied by gelling of protein and appearance of clear whey on the surface of the product. Freshly prepared dahi obtained with two-stage fermentation had lower syneresis (10.28 vs. $11.27 \%$ ) than those obtained by single stage fermentation (Table 1). An elevation in incubation temperature from $45 \pm 1$ to $47 \pm 1^{\circ} \mathrm{C}$ induced a significant increase in syneresis $(2.25$ vs. $11.27 \%$ ) and the resultant product had a weak body in contrast to dahi obtained at an incubation temperature of $45 \pm 1{ }^{\circ} \mathrm{C} .{ }^{26}$ Contraction of the protein strands due to rapid acidification and increased hydrophobic interactions at higher fermentation temperature resulted in a weaker network containing thinner protein strands and thereby higher syneresis. ${ }^{32}$ Cryo-scanning electron microscopy and confocal laser scanning microscopy of buffalo yoghurt denoted a compact microstructure with better viability of probiotic $L$. acidophilus La-5 at lower $\left(37^{\circ} \mathrm{C}\right)$ fermentation temperature but firmer body with a more porous microstructure and a higher degree of syneresis at higher $\left(43^{\circ} \mathrm{C}\right)$ culturing temperature. ${ }^{33}$ Syneresis gradually declined in dahi obtained by the former method but increased in those obtained in latter method after 7 days of storage at $8 \pm 1{ }^{\circ} \mathrm{C}$. A significant decline in syneresis was noted in dahi with the introduction of STI-13 or RST743 , the lowest being recorded for the former culture (4.09\%) than the later (4.82\%). Dahi obtained employing eXact Dahi $2+$ YoFlex Express $1.0+$ STI-13 also had the lowest syneresis (6.54\%) after 7 days of storage at $8 \pm 1{ }^{\circ} \mathrm{C}$. No benefits in terms of syneresis could be achieved with the inclusion of either STI-13 (15.75\%) or RST-743 $(20.15 \%)$ with double strength eXact Dahi 2. Results indicated that STI-13 is capable of elaborating exopolysaccharides in association with eXact Dahi $2+$ YoFlex Express 1.0 and not exclusively with eXact Dahi 2 resulting in the lowest syneresis. Behare et al ${ }^{34}$ reported production of both capsular and ropy polysaccharides by isolated strain of S. thermophilus IG16. Microstructural studies showed that dahi made with EPS-producing strains had relatively compact linear structure with more open structure and pores with discontinuous casein matrix than the controlled dahi. ${ }^{35}$

Lowering of TS of milk from 15.30 to $14.40 \%$ or doubling of YoFlex Express 1.0 inoculum induced no positive effect on extent of syneresis. Dahi obtained from milk (15.30\% TS) employing a starter combination of Dahi + Yoghurt + STI-13 and an incubation temperature of $47 \pm 1^{\circ} \mathrm{C} / 5 \mathrm{~h}$ had the lowest syneresis (6.54\%) after 7 days of storage at $8 \pm 1{ }^{\circ} \mathrm{C}$ (Table 1). Mahdian and Tehrani ${ }^{36}$ reported 
that TS content of the yoghurt samples had significant effect on degree of syneresis and an increase in the TS content results in a reduction in free water content there by wheying off. Penna et al. ${ }^{37}$ concluded that the optimum yoghurt consistency could be achieved from milk containing $14-16 \%$ total solids.

Effect of incubation condition and milk composition on chemical attributes of $d a h i$

\section{Fat content}

Slight decline in fat content of dahi was noted in dahi samples irrespective of starter combinations, size of inoculum, conditions of incubation or duration of storage (Table 2). Hassan and Amjad ${ }^{38}$ reported no change in fat content ( $3.61 \pm 0.56$ to $3.63 \pm 0.56)$ during 8 days of storage of yoghurt at $4{ }^{\circ} \mathrm{C}$. Results of the present investigation also contradict with the earlier reports..$^{39,40}$ Discrepancies may be attributed to adoption of diverse method of preparation, starter cultures and incubation conditions employed.

\section{Protein content}

Milk protein is considered complete proteins as it contains all the essential amino acids our bodies need and consumption of yoghurt with high protein content will help eliminate protein deficiencies. ${ }^{41}$ Lower protein content ( 3.85 vs. $3.92 \%$ ) in dahi was noted with the introduction of two-stage fermentation and being more prominent
(3.96 vs. $4.14 \%$ ) after 7 days of storage at $8 \pm 1^{\circ} \mathrm{C}$ (Table 2). Protein content of dahi enhanced slightly with the introduction of STI-13 $(4.00 \%)$ but significantly with RST-743 $(4.43 \%)$, the highest being observed after 7 days of storage, when used in conjugation with the later organism. Results indicated STI-13 to be more proteolytic than RST-743. An increase in protein content in yoghurt is due to the proteolytic activity of lactic acid bacteria, which hydrolyses proteins (caseins) into peptides and amino acids. ${ }^{42}$ Attempts were also made to obtain dahi by excluding YoFlex Express 1.0 and using double inoculum of eXact Dahi 2. No significant difference in protein content of dahi could be detected with the inclusion of either STI-13 (4.19\%) or RST-743 (4.12\%) after 7days of storage. Hassan and Amjad ${ }^{38}$ also recorded no change in protein content $(4.89 \pm 0.88$ to $4.91 \pm 0.88)$ during 8 days of storage of yoghurt at $4^{\circ} \mathrm{C}$. Bonczar et al..$^{43}$ observed difference in the amounts of individual proteins, which was attributed to different proteolytic abilities of starter cultures used in fermented milk production. Lowering of TS of milk from 15.30 to $14.40 \%$ induced lowering of protein content (4.41to $3.82 \%$ ) and no change could be noted with the doubling the inoculum of YoFlex Express $1.0(3.83 \%)$. The highest protein content in fresh dahi $(4.48 \%)$ was reported when made from high TS $(15.30 \%)$ milk employing a starter combination of eXact Dahi $2+$ YoFlex Express 1.0 + STI-13. Protein content of dahi remained unaltered during 7 days of storage at $8 \pm 1{ }^{\circ} \mathrm{C}$ (Table 2). Consumption of dahi with higher protein content would be advantageous.

Table 2 Effect of incubation condition and milk composition on Chemical attributes of dahi

\begin{tabular}{|c|c|c|c|c|c|c|c|c|c|c|c|}
\hline \multirow{3}{*}{ Starter Cultures } & \multirow{3}{*}{$\begin{array}{l}\text { Incubation } \\
\text { Conditions }\end{array}$} & \multirow{3}{*}{$\begin{array}{c}\text { Total } \\
\text { Solids } \\
(\%)\end{array}$} & \multicolumn{3}{|c|}{$\%$ Fat } & \multicolumn{3}{|c|}{$\%$ Protein } & \multicolumn{3}{|c|}{$\%$ Ash } \\
\hline & & & \multicolumn{9}{|c|}{ After storage at $8 \pm \mathrm{I}^{\circ} \mathrm{C}$ (days) } \\
\hline & & & 0 & 3 & 7 & 0 & 3 & 7 & 0 & 3 & 7 \\
\hline Dahi + Yoghurt & $47 \pm 1^{\circ} \mathrm{C} / 5 \mathrm{~h}$ & 15.30 & 3.30 & 3.07 & 3.08 & 3.92 & 4.34 & 4.14 & 1.02 & 1.01 & 1.01 \\
\hline Dahi + Yoghurt & $\begin{array}{l}1-37^{\circ} \mathrm{C} / 2 \mathrm{~h} \\
1 \mathrm{-}-47 \pm 1 / 3 \mathrm{~h}\end{array}$ & 15.30 & 3.30 & 3.18 & 3.18 & 3.85 & 4.36 & 3.96 & 1.01 & 1.04 & 1.01 \\
\hline Dahi + Yoghurt + STI-I3 & $47 \pm 1^{\circ} \mathrm{C} / 5 \mathrm{~h}$ & 15.30 & 3.27 & 3.28 & 2.99 & 4.41 & 4.10 & 4.00 & 1.00 & 1.03 & 0.99 \\
\hline Dahi + Yoghurt + RST-743 & $47 \pm 1^{\circ} \mathrm{C} / 5 \mathrm{~h}$ & 15.30 & 3.25 & 3.07 & 3.07 & 4.35 & 4.09 & 4.43 & 1.00 & 1.02 & 1.01 \\
\hline Dahi (D) + STI-I3 & $47 \pm 1^{\circ} \mathrm{C} / 5 \mathrm{~h}$ & 15.29 & 3.28 & 3.39 & 3.18 & 4.06 & 4.25 & 4.19 & 1.03 & 1.02 & 1.02 \\
\hline Dahi (D) + RST-743 & $47 \pm 1^{\circ} \mathrm{C} / 5 \mathrm{~h}$ & 15.29 & 3.18 & 3.28 & 3.18 & 4.11 & 4.08 & 4.12 & 1.02 & 1.00 & 1.03 \\
\hline Dahi + Yoghurt + STI-I3 & $47 \pm 1^{\circ} \mathrm{C} / 5 \mathrm{~h}$ & 14.40 & 3.28 & 3.39 & 3.18 & 3.82 & 3.83 & 3.89 & 0.93 & 0.93 & 0.95 \\
\hline Dahi + Yoghurt $(\mathrm{H})+\mathrm{STI}-\mathrm{I} 3$ & $47 \pm 1^{\circ} \mathrm{C} / 5 \mathrm{~h}$ & 14.40 & 3.18 & 3.28 & 3.18 & 3.83 & 3.81 & 3.84 & 0.93 & 0.94 & 0.94 \\
\hline
\end{tabular}

Dahi, eXact Dahi 2;Yoghurt, YoFlex Express I.0;Yoghurt (H), Half inoculum of Yoghurt

\section{Ash content}

Ash content is a reflection of the mineral compositions of the fermented milk. No difference in ash content of dahi could be noted irrespective of starter combinations, size of inoculum, conditions of incubation or duration of storage (Table 2). Hassan and Amjad (2010) $)^{38}$ also recorded no change in ash content $(0.70 \pm 0.10$ to $0.71 \pm 0.10 \%)$ during 8days of storage of yoghurt at $4{ }^{\circ} \mathrm{C}$ due to loss of $\mathrm{CO}_{2}$ and water during charring of yoghurt samples. Result of the present investigation contradicts with previous findings (Hassan et al., 2007, Suliman and El Zubeir, 2014), ${ }^{44,45}$ who reported an increase in ash content in fermented camel milk. ${ }^{40}$ Noted a significant increase in ash content of milk due to fermentation with L. bulgaricus, Lactococcus lactis or L. thermophilus, the highest being observed for first two cultures. Discrepancies in ash content of fermented milk may be due to adoption of diverse method of preparation, starter cultures and incubation conditions employed. However, lowering of TS of milk from 15.30 to $14.40 \%$ induced lowering of ash content (1.00-1.03 to $0.93 \%)$. Ash content of dahi encountered in the present investigation was higher than those reported $(0.52-0.96 \%)$ for yoghurt ${ }^{41}$ indicating more nutritious owing to its higher mineral content.

\section{Microbiological attributes of $d a h i$}

Fresh dahi obtained employing selected starter combination consisting of eXact Dahi 2+YoFlex Express $1.0(\mathrm{H})+$ STI-13 had a total viable count of $6 \times 10^{4} \mathrm{cfu} / \mathrm{ml}$, which attained a peak value of 82 x $10^{7} \mathrm{cfu} / \mathrm{ml}$ after 3days and gradually declined to level of $26 \times 10^{7}$ $\mathrm{cfu} / \mathrm{ml}$ after 7 days of storage. Bozanic et al. ${ }^{46}$ also noted an increment in viable population of yoghurt cultures up to 3days, which declined thereafter and streptococci remained around 5\% higher than the viable cells of lactobacilli. Decline in viable counts may be due to 
inhibition of flora by developed acidity or elaboration of antibacterial compounds. Total viable count detected in the present investigation was within the range $\left(10^{7} \mathrm{cfu} / \mathrm{g}\right)$ to be retained up to the date of minimum durability. ${ }^{47}$ It has been reported that yoghurt cultures do not readily survive stomach acidity (Lick et al., 2001) and therefore health benefits obtained due to its consumption may be attributed to the presence of metabolites or of dead probiotic cells. ${ }^{48}$ Recently a reviewed literature also indicated that inactivated, killed or dead probiotic cells possess functional properties but live cells are more efficacious. ${ }^{10}$

Coliform, Staphylococcus aureus, Escherichia coli, Salmonella and Listeria monocytogens could not be detected in fresh dahi obtained employing selected starter combination comprising of eXact Dahi 2+YoFlex Express 1.0+ STI-13 or during storage (Table 3). Results indicate good manufacturing practices and no post-processing contamination of the product. Sarkar and Misra ${ }^{49}$ also did not detect E. coli, yeast and mould in fresh samples of dahi. Fresh dahi had no yeast $\&$ mould count but it reached to a level of $16 \mathrm{cfu} / \mathrm{ml}$ after 7 days of storage at $8 \pm 1{ }^{\circ} \mathrm{C}$. Earlier studies reported yeast \& mould count of $12 \mathrm{cfu} / \mathrm{ml}$ after 7 days of storage of yoghurt. ${ }^{50}$ Appearance of yeast $\&$ mould count during storage is due to lowering of $\mathrm{pH}$ resulting in creating favourable condition for their growth.

Table 3 Microbiological attributes of dahi

\begin{tabular}{|c|c|c|c|c|c|c|}
\hline Selected Starter Combination & \multicolumn{4}{|c|}{ Total viable count (cfu/ml) } & \multicolumn{3}{c|}{ Yeast \& Mould Count (cfu/ml) } \\
\hline \multirow{3}{*}{ Dahi + Yoghurt (H) + STI-13 } & \multicolumn{5}{|c|}{ After storage at $8 \pm I^{\circ} \mathrm{C}$ (days) } \\
\cline { 2 - 7 } & 0 & 3 & 7 & 0 & 3 & 7 \\
\cline { 2 - 8 } & $6 \times 10^{4}$ & $82 \times 10^{7}$ & $26 \times 10^{7}$ & Nil & 5 & 16 \\
\hline
\end{tabular}

Note: Coliform, Escherichia coli, Salmonella and Listeria monocytogens were not detected during storage.

Dahi, eXact Dahi 2; Yoghurt $(\mathrm{H})$, Half inoculum of Yoghurt

\section{Conclusion}

Results of the present investigation suggests inoculation of milk $(15.30 \%$ TS $)$ with eXact Dahi 2 + YoFlex Express $1.0(\mathrm{H})+$ STI-13 and incubation at $47 \pm 1^{\circ} \mathrm{C} / 5 \mathrm{~h}$ would result in a dahi with a shelf-life of 7 days of storage at $8 \pm 1^{\circ} \mathrm{C}$. Resultant dahi is rich in minerals, possess proteolytic activity and had a total viable counts at a level required for exhibiting health benefits. Ingestion of dahi as a dietary adjunct is suggested due to its higher bio-functionality.

\section{Acknowledgments}

None.

\section{Conflicts of interest}

The authors declare that there is no conflict of interest.

\section{References}

1. Vella MN, Stratton LM, Sheeshka J, et al. Functional food awareness and perceptions in relation to information sources in older adults. $\mathrm{Nutr}$ J. 2014;17:44.

2. Shiby VK, Mishra HN. Fermented milks and milk products as functional foods - a review. Crit Rev Fd Sci Nutr. 2013;53(5):482-496.

3. Yadav H, Jain S, Sinha PR. Oral administration of dahi containing probiotic Lactobacillus acidophilus and Lactobacillus casei delayed the progression of streptozotocin-induced diabetes in rats. J Dairy Res. 2008;75(2):189-195.

4. Vijayendra SVN, Gupta RC. Assessment of probiotic and sensory properties of $d a h i$ and yoghurt prepared using bulk freeze-dried cultures in buffalo milk. Ann Microbiol. 2012;62:939-947.

5. Mohania D, Kansal VK, Kumar M, et al. Francesco Marotta5 modulation of expression of programmed Death-1 by administration of probiotic dahi in DMH-induced colorectal carcinogenesis in rats. Acta Biomed. 2013;84:102-109.

6. Sarkar S, Sur A, Pal R, et al. Potential of dahi as a functional food. Indian Fd Ind. 2011;30:27-36.

7. Sarkar S. Standard of Identity for Probiotic Supplemented Foods. Int J Fd Sci. Nutr Diet. 2013;2:e1.
8. Sarkar S. Innovative Approaches to Upgrade Functional Properties of dahi". Int J Microbiol Adv Immunol. 2016;04(1e):1.

9. Sarkar S, Sur M. Augmentation of biofunctionality of dahi. Int J Dairy Sci. 2017;12:243-253.

10. Sarkar S. Whether viable and dead probiotic are equally efficacious?, Nutr Fd Sci. 2018;48:285-300.

11. Shekar S, Bhat GS. Influence of dissolved oxygen and acid production in buffalo milk by lactic culture. J Fd Protect. 1983;46(4):321-324.

12. FSSAI. Manual of methods of analysis of foods - Milk and milk products, Food Safety and Standards Authority of India, Ministry of Health and Family Welfare Government of India, New Delhi. 2005.

13. BIS. Method of test for dairy industry. Rapid examination of milk", BIS: 1479, Bureau of Indian Standards, Manak Bhawan, New Delhi, India. 1960.

14. BIS. Specifications for dahi”, BIS: 9617, Bureau of Indian Standards, Manak Bhawan, New Delhi, India. 1980.

15. Hempenien WL, Liska BJ. Method of determining volatile acids in cultured dairy products. Journal of Dairy Science. 1968;51: 221-222.

16. Purwandari U, Shah NP, Vasiljevic T. Effects of exopolysaccharideproducing strains of Streptococcus thermophilus on technological and rheological properties of set-type yoghurt. Int Dairy J. 2007;17:13441352 .

17. Lee WJ, Lucey JA. Formation and physical properties of yogurt. AsianAust J Ani Sci. 2010;23:1127-1236.

18. McFeeters RF. Fermentation microorganisms and flavor changes in fermented foods. $J$ Fd Sci. 2004;69(1):35-37.

19. Walstra P, Wouters JTM, Geurts TJ. In: Dairy Science and Technology, Taylor \& Francis Group, Boca Raton, London, New York, Second Edition. 2006;560-569.

20. Shu G, Li C, Chen H, et al. Effect of inoculum and temperature on the fermentation of goat yoghurt. Adv J Fd Sci Technol. 2014;6(1):68-71.

21. Panesar PS, Kennedy JF, Knill CJ, et al. Production of L (+) lactic acid using Lactobacillus casei from whey. Brazilian Arc Biol Technol. 2010;53:219-226. 
22. Ahmad S, Gaucher I, Rousseau F, et al. Effects on the acidification on physical-chemical characteristics of buffalo milk: a comparison with cow's milk". Fd Chem. 2008;106(1):11-17.

23. Varghese KS, Mishra HN. Modeling of acidification kinetics and textural properties in dahi (Indian yogurt) made from buffalo milk using response surface methodology. Int J Dairy Technol. 2008;61(3):284 289.

24. Guler Z, Gursoy-Balci A. Evaluation of volatile compounds and free fatty acids in set types yoghurts made of ewes', goats' milk and their mixture using two different commercial starter cultures during refrigerated storage. $F d$ Chem. 2011;127(3):1065-1071.

25. Tamime AY, Robinson RK. In: Yogurt Science and Technology. New York, USA: CRC Press. 2001.

26. Sarkar S, Sur A, Sarkar K, et al. Process standardization for the manufacture of shrikhand spread. J Nutritional Therapeutics. 2018;7(1):22-30.

27. Dan T, Wang D, Wu S, et al. Profiles of volatile flavor compounds in milk fermented with different proportional combinations of Lactobacillus delbrueckii subsp. bulgaricus and Streptococcus thermophilus Molecules. 2017;22(10):1633.

28. Vijayendra SV, Gupta RC. Performance evaluation of bulk freeze dried starter cultures of dahi and yoghurt along with probiotic strains in standardized milk of cow and buffalo. J Fd Sci Technol. 2014;51(12):4114-4119.

29. Vijayendra SVN, Gupta RC. Associative growth behavior of dahi and yoghurt starter cultures with Bifidobacterium bifidum and Lactobacillus acidophilus in buffalo skim milk. Ann Microbiol. 2013;63(2):461-169.

30. Tamime AY, Robinson RK. Yoghurt: Science and Technology, Cambridge: Woodheed Publishing Limited. 1999; 587

31. Ozer BH, Robinson RK. The Behaviour of starter cultures in concentrated yoghurt (Labneh) produced by different techniques. Lebensm-Wiss- Technol. 1991;32(7):391-395.

32. Lee WJ, Lucey JA. Structure and physical properties of yoghurt gels: effect of inoculation rate and incubation temperature. J Dairy Sci. 2004;87(10):3153-3164.

33. Nguyen HTH, Ong L, Kentish SE, et al. The effect of fermentation temperature on the microstructure, physicochemical and rheological properties of probiotic buffalo yoghurt. Fd Bioprocess Technol. 2014;7(9):2538-2548.

34. Behare PV, Singh R, Tomar SK, et al. Effect of exopolysaccharideproducing strains of Streptococcus thermophilus on technological attributes of fat-free lassi. J Dairy Sci. 2010;93(7):2874-2879.

35. Praveen K. Physico-chemical and microstructural properties of dahi using EPS producing strains, M.Sc. Thesis, National Dairy Research Institute, Karnal, Haryana, India. 2000.
36. Mahdian E, Tehrani MM. Evaluation the effect of milk total solids on the relationship between growth and activity of starter cultures and quality of concentrated yoghurt. American-Eurasian J Agric Environ Sci. 2007;2(5):587-592.

37. Penna ALB, Converti A, De Oliveira MN. Simultaneous effects of total solids content, milk base, heat treatment temperature and sample temperature on the rheological properties of plain stirred yoghurt. $F d$ Technol Biotech. 2006;44:515-518.

38. Hassan A, Amjad I. Nutritional evaluation of yoghurt prepared by different starter cultures and their physiochemical analysis during storage. African J Biotechnol. 2010;9(20):2913-2917.

39. Bahobail AS, Ali AA, Alyan AA. Effect of fermentation process on the improvement of nutrition value of camel milk. Int $J$ Multidisciplinary and Current Res. 2014;2:78-82.

40. Gassem MA, Osman MA, Mohamed Ahmed IA, et al. Effect of fermentation by selected lactic acid bacteria on the chemical composition and fatty acids of camel milk. J Camel Prac Res. 2016;23(2):277-281.

41. Ladokun O, Oni S. Fermented milk products from different milk types. Fd. Nutr. Sci. 2014;5(13):1228-1233.

42. Thomas TD, Mills OE. Proteolytic enzymes of dairy starter cultures. A review. J Fd Microbiol. 1981;46(1987):245-268.

43. Bonczar G, Walczycka M, Duda I. The changes of proteins fractions shares in milk and fermented milk drinks. Acta Sci Pol Technol Aliment. 2016;15(4):379-389.

44. Hassan RA, Zobier EI, Babiker SA. Effect of raw camel milk and storage temperature on chemical composition of fermented camel milk. Int J Dairy Sci. 2007;2(2):166-171.

45. Suliman EK, El Zubeir IEM. A survey of the processing and chemical composition of Gariss produced by nomadic camel woman herders in Al Gadaref State, Sudan. Jordan J Biol Sci. 2014;7(2):95-100.

46. Bozanic R, Tratnik L, Maric O. The influence of goat milk on the viscosity and microbiological quality of yoghurt during storage. Mljekarstvo. 1998;48(2):63-74.

47. Divya JB, Varsha KK, Nampoothiri KM, et al. Probiotic fermented foods for health benefits. Eng Life Sci. 2012;12:377-390.

48. Galdeano CM, Perdigon G. Role of viability of probiotic strains in their persistence in the gut and in mucosal immune stimulation. $J$ Appl Microbiol. 2004;97(4):673-681.

49. Sarkar S, Kuila RK, Misra AK. Effect of incorporation of Gelodan TM SB 253 (Stabilizer cum preservative) and nisin on the microbiological quality of shrikhand. Indian J Dairy Sci. 1996;49:176-184.

50. Hossain NM, Fakruddin M, Islam MN. Development of fruit dahi (Yoghurt) fortified with strawberry, orange and grape juice. $A m J F d$ Technol. 2012;7:562-570. 